\title{
Do Completed College Majors Respond to Changes in Wages?
}

\section{Mark C. Long ${ }^{\mathrm{a}}$, Dan Goldhaber ${ }^{\mathrm{b}}$, and Nick Huntington-Klein ${ }^{\mathrm{c}}$}

\begin{abstract}
In an analysis connecting labor market earnings to college major choices, we find statistically significant relationships between changes in wages by occupation and subsequent changes in college majors completed in related fields of college study between 1982 and 2012. College majors (defined at a detailed level) are most strongly related to wages observed three years earlier, when students were college freshmen. The responses to wages vary depending on the extent to which there is a strong mapping of majors into particular occupations. We also find that women, blacks, Hispanics, and students with low test scores are less likely to respond to wage changes. These findings have implications for policy interventions designed to align students' major choices with labor market demand.
\end{abstract}

Acknowledgement: We thank Julie Cullen, Mark Duggan, Harry Holzer, Robert Kelchen, Jake Vigdor, participants at the $7^{\text {th }}$ CALDER (National Center for Analysis of Longitudinal Data in Education Research) Research Conference and Association for Education Finance and Policy Conference for helpful discussion and comments, and the State of Washington's Education Research \& Data Center for access to data. This research was supported in part by CALDER's postsecondary initiative funded through grants provided by the Bill \& Melinda Gates Foundation and another foundation who wishes to remain anonymous to the American Institutes for Research. This research was additionally supported in part by the Collaborative Researchers for Education Sciences Training grant provided by the U.S. Department of Education's Institute of Education Sciences.

JEL Codes: J24, J31, I23

${ }^{a}$ Corresponding author. marklong@uw.edu. (206) 543-3787. Evans School of Public Affairs, University of Washington, Box 353055, Seattle, WA, 98195

bdgoldhab@uw.edu. Center for Education Data and Research, 3876 Bridge Way N., Ste 201, Seattle, WA 98103

cnhuntington-klein@fullerton.edu. Department of Economics, California State University

Fullerton, Fullerton, CA 92834 


\section{Do Completed College Majors Respond to Changes in Wages?}

\section{Introduction}

The enormous effect of the Great Recession on the labor market and college budgets has heightened long-standing debates about the fields of study in which college students should major. Some contend that students do not sufficiently consider the economic consequences of their major choices and should be encouraged to pursue majors in high demand in the labor market (e.g., Singletary, 2012; Olson, 2012). The presumption here is that an insufficient student response to labor market cues may affect not only their own economic well-being but also the quality of jobs available to workers in the U.S. (Holzer, 2012).

There are several possible policy responses to address the potential that market failures lead to suboptimal student choices. One might, for instance, make the economic consequences of college major choice more explicit to students (Carnevale et al., 2011, 2012), or encourage students to pursue the 'right' majors by changing the relative price of different majors through differential tuition policies, targeted loans, or loan forgiveness. Some argue that majors with high labor market demand ought to be subsidized in order to encourage higher enrollment in those areas. Such a policy has been suggested by a blue ribbon task force on higher education reform in Florida, and advocated by Florida Governor Rick Scott. ${ }^{1}$ Finally, colleges could react to the labor market by expanding departments that train students for high demand fields.

Whether or not such policy interventions may be justified, and the efficacy of different types of interventions, depends on the degree to which students are sensitive to the labor market

\footnotetext{
${ }^{1}$ Interestingly, however, in contrast to the idea of subsidizing in-demand majors, a number of higher education institutions have increased tuition in majors such as engineering and the physical sciences so as to better align tuition with the cost of instruction, and because students graduating in a high-demand major can afford higher tuition rates with their higher future salaries (Ehrenberg, 2012).
} 
returns associated with college majors. Interestingly, there is little empirical evidence on this basic labor market issue. We address this gap by estimating the response of completed college majors to changes in wages in occupations associated with those majors. We estimate these lagged responses using aggregated national Integrated Postsecondary Education Data System (IPEDS) and Current Population Survey (CPS) data from 1987-2011 and individual-level longitudinal data from the State of Washington from 2007-2012. Our null hypothesis is that completed majors in a particular field in year $t+y$ have no relation to wages in associated occupations in year $t$, while the alternative hypothesis is that majors rise in year $t+y$ in response to wages in in associated occupations in year $t$. Further, we assess whether: 1) majors respond to national and/or local labor market wages; 2) larger majors or majors more tightly connected to particular occupations are more responsive to wages; and 3) whether there is heterogeneity in response by student characteristics.

We find statistically significant relationships between wages and majors at both the national and state level and with majors defined at both detailed and aggregated levels. Bachelor's degrees produced in year $t$ in detailed majors are most strongly associated with wages in year $t-3$, which suggests that college majors respond most to wages when students are (roughly) college freshmen. ${ }^{2}$

We also find that the response is stronger for those majors that have a tight connection to relatively few occupational choices, such as nursing. Our results from Washington state confirm the national analysis, and we also find more response to wages earned by recent graduates from public institutions in Washington than to wages earned by all bachelor's degree holders in the state or nationwide. Finally, we show that women, African-American and hispanic students, and

\footnotetext{
${ }^{2}$ The median time to degree for 2008 bachelor's degree recipients was 4.33 years (Cataldi et al., 2011).
} 
those with low SAT scores are less likely to respond to changes in local wages than other students: responses for women and those with low SAT scores are less than half of men and high-SAT students, respectively. Estimated responses of black and Hispanic students to wages

are nonsignificant, small, and negative. We cannot say whether the lower response rates for these types of students are related to the types of labor market information those students receive or differences in preferences for major.

For an average sized major, an increase in that major's wages of $10 \%$ relative to the wages of other majors would lead the share of degrees earned in that major to increase from $2.07 \%$ to $2.21 \%$, a figure which implies a world in which degree production does not align strongly with labor market demands. If policy goals entail a strong alignment, these results could act as justification for policy which guides student choice and/or elicits more institutional response. While many of the college majors which are at the center of policy interventions, in particular STEM majors, are among those with relatively stronger responses to wages already, some policy makers may consider the response to be still too weak.

\section{Theoretical Framework}

The theory undergirding our analysis is simple: students should increase their likelihood of majoring in discipline $d$ and colleges should expand access to majoring in discipline $d$ if they anticipate that there are increasing economic rewards associated with majoring in discipline $d$. Futher, students and colleges should gauge the economic rewards associated with majoring in discipline $d$, at least in part, based on the labor market outcomes for students who recently 
received degrees in this discipline. ${ }^{3}$ This theoretical framework, which we detail below, illustrates the method we take to assign a market wage to each college major.

We illustrate this theoretical framework in Figure 1. In this stylized example, the labor market demand curve in this graph is a weighted average of labor demand for employees in occupations associated with major $d$, with weights based on the share of workers who previously majored in $d$ and are now employed in occupation $o$. Likewise, the labor supply curves in this graph is a weighted average of the labor supply curves for workers in the occupations associated with major $d$.

In Figure 1, we show an increase in wages in occupations associated with major $d$ due to an increase in labor demand in occupations associated with major $d$.

\section{[Insert Figure 1 here]}

As long as informational deficiencies and frictions are not too severe (e.g. transaction costs associated with swtiching majors, university capacity constraints, ${ }^{4}$ etc.), the increase in demand will increase the number of students training in the major and shift the short-run labor supply for related fields to $\mathrm{SRS}_{\infty}$. Further, a lack of perfect information or frictions in labor supply - such as if there are university capacity constraints or if some students lack the skills necessary to be successful in a particular major (and recognize this) - will yield a LRS with a

\footnotetext{
${ }^{3}$ While we focus on the short run connection between wage changes and academic major, we want to acknowledge that wages are not the only labor market outcome that students may care about. For instance, students and colleges might also respond to the relationship between college major and unemployment or to the stability of wages over a career (Carnevale et al., 2012). Students and colleges may also respond to the variance of current wages associated with a particular major. Unfortunately, the data do not permit us to delve into these issues in any detail. ${ }^{4}$ For example, it is argued that a shortage of nursing faculty thwart some students from pursuing undergraduate degrees in nursing (American Association of Colleges of Nursing, 2009). Institutional constraints may keep capacity from fully adjusting in the long run.
} 
positive slope. ${ }^{5}$ The positive slope on the LRS means that the demand shock translates into a persistent increase in wages, a necessary finding in order to suggest that it is individually rational to respond to wage shocks. The thick line with arrows on Figure 1 reflects the expected time path of wages moving from $\mathrm{W}_{0}$ to the long-run $\mathrm{W}_{\infty}$.

We test whether we actually find persistence in wage increases by calculating wage impulse response functions (IRFs) for the 30 majors with the largest enrollments. ${ }^{6}$ The degree to which wage shocks can be treated as persistent is reflected in these IRFs in Figure 2.

The mean IRF, which is shown by the thick line, shows that a wage shock in year $t$ is more than $50 \%$ eroded by year $t+5$ and $80 \%$ eroded by year $t+10$ for a typical major. In effect, what we find is that at the mean, there is not sufficient "crowding out" to totally cancel out a wage shock even after ten years, suggesting that students interested in increasing their lifetime earnings would be able to do so by responding to wage shocks, in accordance with our theory as presented in Figure 1.

\section{[Insert Figure 2 here]}

College students, however, face several difficulties in responding to wage shocks. For instance, as is clear from the IRFs across different majors in Figure 2, there is substantial variation across majors. Some majors show $50 \%$ or greater persistence by year $t+10$ and some majors show no persistence by year $t+10 .^{7}$ In fact, students as well as colleges face several

\footnotetext{
${ }^{5}$ For example, a student with very little mathematical skill will have little opportunity to successfully respond to an increase in wages for physics majors. See Goldin and Katz (2008) for a broader discussion of why we might see persistent wage premiums in some fields.

${ }^{6}$ To compute these IRFs, we computed the major's wage (using the methods and data we describe below in Section 4.1 that maps wages to majors) and ran a vector autoregression of $W_{t}$ on three lags ( $W_{t-1}, W_{t-2}$, and $\left.W_{t-3}\right)$ and then computed a forecast horizon to $t+10$. See www.stata.com/manuals13/tsirf.pdf.

${ }^{7}$ Among these 30 majors, the IRF for English Language \& Literature was closest to the mean IRF (based on mean absolute value differences). Psychology has the IRF with the greatest wage persistence (i.e., the highest line on the chart), Political Science \& Government is the fastest to
} 
substantial hurdles in making a reasonable forecast of this wage time path and deciding how to respond. First, they would need to be aware of the strength of the connection between major $d$ and each occupation. Second, they would need to be aware of an increase in wages in occupations associated with major $d$, and the magnitude of that increase. Third, they would need to estimate long-run wages $\mathrm{W}_{\infty}$ by forecasting the speed and size of the response to the wage increase made by other students and colleges (a difficult task even for the Bureau of Labor Statistics, as pointed out by Steckler and Thomas, 2005). Fourth, they would need to estimate the labor demand elasticity for each associated occupation. Fifth, students would need to discount this future time path to arrive at the present value of the wage increase for major $d$. These sources of uncertainty - both econometric uncertainty and the uncertainty associated with the complexity of the problem - have significant implications for the structure of the choice problem faced by students and colleges (Altonji, Blom, and Meghir, 2012). ${ }^{8}$

Public availability of more usable information about wages has improved of late. Specifically, the inclusion of a field of study variable in the ACS data beginning in 2008 allows a more rigorous public presentation of wages by detailed major, with the report by Carnevale et al. (2012) receiving wide news coverage (e.g., National Public Radio, 2013). Payscale.com has also become a source of information about the wages associated with different college majors (based

have nearly complete erosion by $t+5$, and Nursing Assistant is the major with negative wage persistence for every period beginning with $t+6$.

${ }^{8}$ One could argue that students are able to form sophisticated expectations of future returns "asthough" they were estimating them econometrically. For example, Buchinsky and Leslie (2010) show how individuals can construct uncertainty-aware forecasts of education-conditional wages using contemporaneous information. However, this kind of foresight applied to the choice of getting additional years of education may not apply to the more daunting task of forecasting wages by major. 
on their users' data input). ${ }^{9}$ These sources of data provide more usable information to students and colleges which could make it easier for them to respond to wage changes.

However, studies which investigate the information that college students actually have about wages reflect the difficulty facing students even when information is accessible. Perceived wages are linked to student choice, but student estimates of wages for particular majors and for college in general are typically imprecise and/or inaccurate (Betts, 1996; Wiswall and Zafar, 2015). Student estimates are found to become more accurate over time and be more precise for one's own major (Botelho and Pinto, 2004; Arcidiacono, Hotz, and Kang, 2011; Zafar, 2011). It may be the case that students mostly learn about future wages for a major they have already committed to, after it is likely too late to switch.

\section{Literature on Choice of College Major}

There exists wide variation in salaries across different occupations, so a worker's choice of occupation has the potential to have a tremendous effect on lifetime earnings. A significant amount of empirical evidence suggests that earnings potential affects individuals' choice of occupation (e.g. Boskin, 1974; Siow, 1984; Zarkin, 1985). Similarly, it is clear that there are significant differences in earnings according to one's major (Carnevale et al., 2012), and recessions and economic fluctuations can have significant and persistent effects on new college graduates that depends, in part, on the major with which they enter the labor market (Oreopoulos, von Wachter, and Heisz, 2012; Liu, Salvanes, and Sorensen, 2012). However, there is less

\footnotetext{
${ }^{9}$ To see examples of how the popular media is conveying this information, see Goodreau (2012), Izzo (2012), Payscale, Inc. (2013), Singletary (2012), Wall Street Journal (2013), National Public Radio (2013), and Stewart (2013).
} 
definitive evidence on the extent to which lifetime earnings considerations factor into college major choices.

Empirical evidence tends to suggest that the influence of future earnings on college major decisions may be quite small, with the choice of major more driven by the consumption value of different fields (Arcidiacono, 2004; Beffy, Fougère, and Maurel, 2012; Wiswall and Zafar, 2015), field-specific aptitudes (Arcidiacono, Hotz, and Kang, 2012; Freeman and Hirsch, 2008; Stinebrickner and Stinebrickner, 2014), or the pricing of particular majors (Stange, 2015). The primacy of consumption value appears to hold even in situations where particular majors are known to be strongly linked to certain occupations (Alstadsaeter, 2011).

Work that focuses on connecting field of study to potential future earning generally relies on strong forecasting assumptions, in which a student's expectation of their future earnings is equal to a prediction of an econometric model trained on actual future earnings. Berger (1988), for instance, estimates the relationship between a college student's predicted future earnings and choice between five broad fields of study. He finds evidence suggesting that students are likely to choose majors that offer greater predicted lifetime earnings streams (as opposed to responding primarily to initial earnings). Beffy et al. (2012) likewise estimate the relationship between expected earnings and college major across broad fields of study. They attempt to account for self-selection by exploiting variations in the relative earnings returns induced by the business cycle. They find heterogeneous responses to changes in anticipated earnings and conclude that the elasticities of major choices are modest and primarily driven by non-pecuniary factors. Like Berger, Beffy et al. derive anticipated earnings using forward-looking data. Student expectations are assumed to be based on earnings among those in the same cohort, which are not realized at the time the major choice decision is made. 
The assumption that students expectations are best matched by data not yet generated at the time the student makes the decision is strong. We instead assume that student expectations are based on data that already exists at the time the decision is made. As such, the research in this paper is closest in spirit to Boudarbat and Montmarquette (2007) who assume that college students from a particular cohort base their decisons on what they learn about earnings by major from prior cohorts. They find that the estimated effects of initial earnings on choice varies by both gender and the education level of a students' parents, but generally suggest that students do respond to earnings information.

Our study contributes to the above literature in several ways. First, our analysis does not rely on future data on earnings outcomes to calculate anticipated returns to different majors; rather, we assume that students' college major choices are influenced by wage information that is received during or before their college career, and students and colleges respond because there is some permanence in wage changes. Second, unlike prior studies, including all of those cited above, we estimate the relationship between college major and labor market earnings using detailed definitions of college majors and related occupational earnings, rather than using a small number of aggregated categories. Using detailed majors allows us to assess whether the relationship between wages and completed majors varies according to the tightness of the mapping between majors and occupations, or based on the size of the major. Third, we utilize a relatively long longitudinal panel of wage and major choice information so that we can evaluate the types of labor market information to which students and colleges appear to respond. Fourth, we compare findings from national samples to those at the state level, which permits an assessment of whether students and colleges respond to more localized (state or college specific) information about prospective wages. Finally, we are able, using the data from Washington state, 
to assess the degree to which there are heterogeneous responses to information according to student's prior academic acheivement, gender, and race/ethnicity.

\section{Methods}

\subsection{National Analysis}

We begin by testing our hypothesis that wages in prior years are related to completed majors in year $t$, using a Granger (1969) test. We test whether wages in years $t-1$ to $t-6\left(W_{d t-1}\right.$ to $W_{d t-6)}$ in occupations associated with discipline $d$ (the relationship between disciplines and occupations is defined below) significantly predict the share of majors in discipline $d$ in year $t$ $\left(M_{d t}\right)$ when controlling for the share of majors in discipline $d$ in years $t$ - 1 to $t-6$. It is important to note that a test of "Granger-causality" is, despite the name, simply telling us whether the prior year wages are useful for predicting majors in year $t$, not necessarily whether changes in wages caused the change in majors.

For each major, we conduct the following vector autoregression:

$$
M_{d t}=\alpha+\beta_{1 d} M_{d t-1}+\beta_{2 d} M_{d t-2} \ldots+\beta_{6 d} M_{d t-6}+\gamma_{1 d} W_{d t-1}+\gamma_{2 d} W_{d t-2} \ldots+\gamma_{6 d} W_{d t-6}+\varepsilon_{d t}
$$

A Wald test is conducted to assess the hypothesis that the gamma coefficients are jointly zero. We run these regressions for each of 36 major groups at the 2-digit level of CIP codes and for 1,062 6-digit majors. ${ }^{10}$ We report the weighted average p-value from these Wald tests, weighted by the discipline's average share of all majors. We also report the frequency by which we reject the null hypothesis across the majors we study.

\footnotetext{
${ }^{10}$ As an example of what these 2- and 6-digit majors include, "Engineering" is a 2-digit major group which spans many 6-digit majors including "Structural Engineering," "Laser and Optical Engineering," and "Chemical and Biomolecular Engineering." For details, see https://nces.ed.gov/ipeds/cipcode/Default.aspx?y=55.
} 
Our second analysis evaluates the strength of the connection between wages and majors and the lag time between the two. For this analysis, we calculate the correlation of the share of all degrees completed in discipline $d$ in year $t$ with the relative wages of discipline $d$ in year $t-y$. Figure 3 illustrates this computation for Registered Nurse Training (which we will hence just call “nursing”). As shown below, across a 30 year span students who earned bachelor's degrees in nursing had wages that were, in an average year, 39\% greater than persons who earned degrees in other disciplines. However, the relative wages of nurses varied quite a bit, rising steadily in the late 1980s, peaking in 1992, and falling through 2000 before rising again. The time path for the share of students earning bachelor's degrees in nursing had a similar, albeit delayed time path, rising in the mid-1990s, falling in the late 1990s, and rising again after 2002 to over $4 \%$ of all majors in 2011. We measure the correlation between the two time series; for majors measured in year $t$ and associated wages measured in $t-6, t-5, \ldots$, and $t-1 .^{11}$ The correlation between nursing's share of all majors in year $t$ and the wages of those who major in nursing in year $t-4$ is 0.387 .

\section{[Insert Figure 3 here]}

We conduct this same correlation computation for each of 36 major groups at the 2-digit level and each of the 1,062 different majors at the 6-digit CIP level. We then compute the weighted average of these major-specific correlations using discipline $d$ 's average share of majors across all years as its weight (e.g., nursing would get a weight of about 0.032 as this is its

\footnotetext{
${ }^{11}$ As noted above, we are simply evaluating the reduced-form relationship between completed majors in year $t$ and wages of associated occupations in a prior year. We are not estimating the short-run or long-run labor supply curve shown in Figure 1, and thus we do not face the typical identification problem when one tries to estimate a labor supply curve. Further, note that an increase in the number of majors in year $t$ has a small effect on the existing labor supply of workers already trained in the associated occupations, and thus this flow only modestly affects the labor supply stock in associated occupations in year $t+1$, which is why there is some persistence in the increased wage as shown in Figure 1.
} 
average share of majors). To compute the standard error of the weighted average correlation, we (1) randomly shuffle 1983-2012 wage histories across majors (e.g., the wage history of nursing may be randomly allocated to psychology), (2) compute the weighted average correlation of wages and major share that emerges from this random shuffle, (3) repeat steps 1 and 2100 times, and (4) compute the standard deviation of the weighted average correlation produced in these 100 iterations. ${ }^{12}$ To further show the strength of these relations, we run the following regression for each discipline, with wages measured with various lags $y$, and compute the weighted average value of $\beta_{d}: M_{d t}=\alpha+\beta_{d} W_{d t-y}+\varepsilon d t$

To do the analyses described above, we first need to compute wages in year $t$ for each discipline $d$. To construct the time series of discipline $d$ 's wages, we first map majors to related occupations, and then compute a weighted average of wages earned in related occupations. Using the actual pattern of occupational employment by major as found for ACS survey respondents in the years 2009 to 2011, we find the share of major $d$ individuals who work in occupation $o$ and set this share as the weight when computing the weighted average wages for major $d$ in year $t .^{13}$

The ACS is the only data set that links majors detailed at the 6-digit CIP level with occupations and that has a large enough sample to give accurate mapping from majors to occupations at a detailed level. ${ }^{14}$ However, since the ACS has only been collecting information

\footnotetext{
${ }^{12}$ This method is used to address the serial correlation in wages and major shares present in the data. For a broader discussion of the use of bootstrap methods involving clusters of data, see Cameron, Gelbach, and Miller (2008).

${ }^{13}$ Note that this approach takes into account the pathways from particular majors to graduate school and then into the labor market. So, for example, if a decent share of philosophy majors go onto law school, this approach will capture the extent to which philosophy majors should be looking at the wages of lawyers.

${ }^{14}$ We crosswalk the ACS field of study codes to six digit CIP codes by hand. The ACS codes are in the majority of cases directly comparable to the CIP, and the crosswalk is available from the authors.
} 
on college majors for a few years, using these data requires that we assume that the mapping we observe for 2009 to 2011 would also hold for earlier years. This is a strong assumption, especially since occupational choice conditional on major should shift in response to market forces. To evaluate whether our mapping procedure is reasonable, we consider two alternatives. First, in results available in the working paper version of this paper, we replaced the ACS mapping using the major to occupation crosswalk developed collaboratively by the National Center for Education Statistics and the Bureau of Labor Statistics (NCES/BLS, 2011), which identifies occupations that the major prepares students for rather than actual employment patterns. Using this mapping, we found similar results.

Second, to evaluate the possibility of changes in the mapping over time, we compare the major/occupation mapping in the 1979 and 1997 cohorts of the National Longitudinal Survey of Youth (NLSY) at 14 years after the original survey (which is the last available wave for the 1997 cohort as of the current writing). Since the sample in the NLSY is much smaller than that of the ACS, ${ }^{15}$ we look at majors at a very broad level, aggregating them to the 27 major groups reported in the NLSY and13 broad occupation categories, ${ }^{16}$ yielding 351 major-occupation cells. Even with this broad aggregation, there are only an average of about four survey respondents per cell. For each of the 27 major groups, we compute the correlation of the number of graduates holding a particular occupation in 1979 and 1997. We then average this correlation over all majors. The average correlation is 0.71 (un-weighted) or 0.87 when weighted by the minimum of the number of survey respondents in the 1979 and 1997 cohorts who selected that major. Only 13 of these 27 majors had more than 20 survey respondents in both cohorts. Of these 13 majors, 11

\footnotetext{
${ }^{15}$ Limiting the NLSY samples to those who completed a bachelor degree and with data on major and occupation, results in roughly 1,500 persons in each sample.

16 These occupation categories were determined by the broad categorizations made for the 1990 Census Occupation classification system.
} 
had the same top occupation category in 1979 and 1997 . Yet, it should be noted, that the most popular occupation was usually the very broad category "Professional Specialty Occupations," which includes occupations as diverse as Architect, Librarian, and Dancer. Given the strong limitations posed by the smaller sample sizes, the NLSY data is of limited use in determining stability across time in major-to-occupation mapping. That said, using these broad categories, the results suggest strong stability across the two cohorts.

To assess whether there is more response to wages in majors that have tighter connections to particular occupations; we compute each major's index of qualitative variation (IQV), which ranges from 0.0 (when all persons with major $d$ are employed in occupation $o$ ) to 1.0 (when persons with major $d$ are evenly spread across all occupations). ${ }^{17}$ We split the sample of majors into quartiles based on IQV and estimate the correlations described above for the topquartile, second-quartile, and bottom half of majors.

The IQV measurement has face validity in the sense that it appears to match common perceptions of what it means to have a tight or loose connection between majors and occupations. For example, among the "tight" majors are many job-targeted fields, such as Petroleum Engineering (IQV of .646) and among the "loose" majors are many more general fields such as Geography (IQV of .985). Consistent with this, there is a strong negative correlation $(-0.51, \mathrm{p}$-value $<0.001)$ between the major's IQV score and the standard deviation of the major's wages. That is, majors that are tightly connected to particular occupations have wages that are more highly variable across time. This result should not come as a surprise as majors with looser connections are drawing wages from many occupations and averaging across

\footnotetext{
${ }^{17}$ We calculate IQV using the M2 index (Gibbs and Poston, 1975): $I Q V_{d}=\frac{K}{K-1}\left(1-\sum_{o}^{K} p_{d o}^{2}\right)$ where $p_{d o}$ is the share of graduates of discipline $d$ who end up in occupation $o$ and $K$ is the total number of occupations.
} 
these occupations yields more stability. ${ }^{18}$ As a result, for tightly connected majors there is more variation in wages to which students can respond. Thus, there are two reasons why it may be easier to observe changes in wages for majors that are more tightly connected to particular occupations; (1) they present less of a challenge for students to gather information on likely wages as there are fewer occupations for which the student needs to track, and (2) they have more wage variation which makes shifts in wages more apparent. ${ }^{19}$

Finally, to assess whether students are more responsive to wages in popular majors, we restrict the sample to the largest majors that, respectively, enroll $90 \%, 75 \%$, and $50 \%$ of total enrollment, and estimate the correlations described above for these restricted samples.

While we use causal language above in describing correlations of wages in year $t$ with majors in year $t+y$ (e.g., by using the word "responsive"), we fully recognize that there are limitations in asserting causality. A causal interpretation requires the assumption that there are not omitted factors that influence wage changes and are also correlated with college major choices. For example, suppose that working in the tech industry gets popular for some exogenous reason (e.g., due to positive media coverage). If suddenly people started trying to get tech jobs that would put downward pressure on wages. If, simultaneously, college students decided to enroll in tech-related majors in response to the same stimuli, we would then see a negative correlation between wages and majors in year $t$. Such an event would bias our correlational

\footnotetext{
${ }^{18}$ Note that measurement error in wages in likely to be more of an issue for majors with tighter connections to particular occupations as the wage for that major will be based on fewer occupational wage estimates. Thus, if there is such heterogeneity in measurement error across these samples, it would tend to bias downward correlations estimated for the majors with the tightest connections.

${ }^{19}$ Ransom (2014) finds persistence of the rankings of majors by their degree of tightness to particular occupations, using data from National Survey of College Graduates for 1993, 2003, and 2010 .
} 
findings downward. Findings could additionally be biased downward by measurement error in the major/occupation mapping.

\subsection{Washington State Analysis}

Our second analysis is designed to assess the degree to which more localized local labor market information might have more influence on completed majors, and whether there is heterogeneity in the response to this information. Specifically, we analyze the likelihood of degree completion by major in Washington State using administrative data on undergraduates.

We answer the following question: Do students' completed majors shift towards more lucrative majors as measured by (a) the wages earned by recent graduates of their university, (b) recent graduates of public state universities in Washington, (c) all bachelor's degree holders in Washington, and/or (d) all bachelor's degree holders in the nation?

To examine how completed majors in 28 2-digit disciplines ${ }^{20}$ respond to changes in discipline-specific wages, we use the following alternative-specific conditional logit:

(2) $\quad p_{\text {diut }}=\frac{\exp \left(\alpha_{d}+\beta \ln W_{d u t-y}+\gamma_{d} X_{i}+\theta_{d} U_{u}\right)}{\sum_{d=1}^{28} \exp \left(\alpha_{d}+\beta \ln W_{d u t-y}+\gamma_{d} X_{i}+\theta_{d} U_{u}\right)}, \quad d=1, \ldots, 28$,

$p_{d i u t}$ is the likelihood of student $i$ in university $u$ completing a degree in discipline $d$ in academic year $t$ (i.e., September-August). $W_{d u t-y}$ is our measure of wages in discipline $d$ at university $u$ in academic year $t-y$ (where $y$ is the number of years by which the wage is lagged). We use log wages so that the coefficient can be interpreted as the response to a percentage change in

\footnotetext{
${ }^{20}$ Several two-digit CIP codes are not used because no college in the sample offers a bachelor's degree in that major group. We conduct this analysis at the 2-digit level because at a finer level the number of observations for many of the majors is too small, and using a 6-digit level would be computationally challenging as it would require the estimation of many thousands of coefficients, with one coefficient for each student characteristic control variable multiplied by the number of choices.
} 
wages. ${ }^{21} X_{i}$ is a vector of demographic variables including gender, race (non-Hispanic white, non-Hispanic black, non-Hispanic Asian, and Hispanic), ethnicity, age and age squared, dummies indicating high, low, or missing entrance exam scores,${ }^{22}$ and dummies indicating freeor reduced-price lunch (FRPL) status in high school. FRPL data is available for virtually all students who attended high school in Washington State, so indicators of missing FRPL status is included as a proxy for students who are enrolled in Washington institutions from out of state. $U_{u}$ is a vector of university dummies to capture non-wage variation in the popularity of disciplines across universities.

The parameter of interest in Equation 2 is $\beta$, which represents the response of major to changing log wages. Our hypothesis is that $\beta$ should be positive: students should be more likely to choose discipline $d$ if that discipline has become relatively more lucrative. We measure wages in three additional ways to get a sense of whether wage information at a less local level is more salient for students' major choices. In alternate specifications, $W_{d u t-y}$ is replaced with $W_{d t-y}$ (i.e., dropping the $u$ subscript) and wages are computed at the state level (using either recent graduates of state universities or all Washington bachelor's degree holders) or national level (using all U.S. bachelor's degree holders). We run this specification using lags of $t-3, t-2$, and $t-1$. In all cases, marginal effects are calculated using simulation by adding 0.01 to $W_{d u t-y}$, computing $\Delta p_{\text {diut }}$, and then multiplying this change by 100 .

\footnotetext{
${ }^{21}$ Again note that while we use causal language in describing the relationship between wages in year $t$ with major choices in year $t+y$ there are limitations in asserting causality in this state-level analysis, just as there is in the national analysis.

${ }^{22}$ A "high" score is above 1000 on the combined math and reading SAT exams. If SAT scores are not reported but ACT scores are, the equivalent ACT score of 22 or above on math and reading is used (ACT, 2014). A dummy for no reported entrance exam score is also included.
} 
To evaluate the possibility of heterogeneity in responses, we allow the response (i.e., $\beta$ ) to vary by adding interactions of $W_{d u t-y}$ with gender, race, test scores, and FRPL status. ${ }^{23}$ To compute marginal effects for each subgroup, we add 0.01 to $W_{d u t-y}$, and compute the mean of $100 \times \Delta p_{\text {diut }}$ for each subgroup. To obtain the standard error for this mean marginal effect, we use a bootstrapping approach, by computing the mean marginal effect for each subgroup for each of 100 bootstrapped samples (each sample consisting of $0.5 \times N$ observations) and then computing the standard deviation of these 100 mean marginal effects. Finally, we compute the difference in the mean marginal effects across subgroups (e.g., the mean marginal effect for females minus the mean marginal effect for males), and generate one-tailed p-values for the difference in mean marginal effects. We estimate the p-value of the difference by counting the number of iterations out of 100 in which group 1 had a larger mean marginal effect than group 2.

\section{Data and Empirical Counterparts}

\subsection{National Data on Majors}

The data on completed degrees by major for the years 1987 to 2011 are taken from the Integrated Postsecondary Education Data System (IPEDS), collected by the U.S. Department of Education. Since CIP codes have changed periodically over time, we crosswalk all 6-digit codes to their 2000 values using the crosswalks supplied by NCES (2013). ${ }^{24}$ The IPEDS data is then collapsed by year to compute the total number of degrees produced in each 6-digit CIP, and

\footnotetext{
${ }^{23}$ We drop the campus fixed effects in this analysis as the added interaction terms make model convergence more difficult. In results not shown, we obtained relatively robust results for the non-interacted specification when we included or excluded campus fixed effects.

${ }^{24}$ For the years 1987-91, we first crosswalk CIP1985 to CIP1990. Then, for the years 19872002, we crosswalk CIP1990 to CIP2000. For the years 2010-11, we crosswalk CIP2010 to CIP2000.
} 
these totals are then converted into shares for year $t$. We then collapse these shares to the 2-digit CIP level.

\subsection{National Data on Wages}

The data on wages by occupation for the years 1983 to 2012 are taken from the Current Population Survey's (CPS) Merged Outgoing Rotation Groups using the extracts provided by the National Bureau of Economic Research (2013). We define occupations using 3-digit SOC codes. These SOC codes have also changed periodically over time, thus we use the "proposed standard code" in Appendix A of Meyer and Osborne (2005) to crosswalk these codes. ${ }^{25}$ For each of these occupations, we compute the average of weekly earnings (weighted using an individual's “earnings weight" as provided by the CPS). To compute the occupation's relative wages, we then divide this figure by the weighted average of weekly earnings for all occupations in year $t$.

\subsection{Washington State Data on Major and Wages}

Data for the Washington state analysis comes from the Education Research \& Data Center (ERDC), and includes 58,511 students who graduated with a bachelor's degree from one of eight large public universities in Washington between fall 2007 and spring $2012 .{ }^{26}$ Students' administrative records and demographic characteristics are matched to Unemployment Insurance (UI) data that includes students' wages after graduation. ${ }^{27}$

\footnotetext{
${ }^{25}$ Prior to doing this crosswalk, for the years 2011-12, we first crosswalk 4-digit SOC2010 to 4digit SOC2002 using the crosswalk supplied by U.S. Census Bureau (2013) and then collapse to 3-digit codes.

${ }^{26}$ These are: University of Washington campuses at Seattle, Tacoma, and Bothell; Washington State University campuses at Pullman, Spokane, Vancouver, and Tri-Cities; and Eastern Washington University.

${ }^{27}$ Students are linked to UI wage data using the Social Security Number provided in their baccalaureate records. UI wage data does not include those who are self-employed or those employed by the military, but since this is likely a small percentage of those with recent bachelor's degrees, their omission is not likely to significantly bias wage means.
} 
The earned wages associated with a particular discipline $d$ in time $t$ at university $u$ is the mean first-year total wages of all students who graduated with a bachelor's degree in $d$ from university $u$ in academic year $t$. For our alternate wage measures, we instead use mean first-year total wages of all students who graduated with a bachelor's degree in $d$ from any of the eight public Washington universities in academic year $t$ using UI records; CPS estimates of average weekly earnings of Washington workers with bachelor's degrees working in occupations associated with discipline $d$; or CPS estimates of average weekly earnings of U.S. workers with bachelor's degrees working in occupations associated with discipline $d$. CPS and ERDC-derived wages are strongly correlated. Each of the CPS measures has a correlation of about .65 with each of the ERDC measures. This can be compared to a correlation of about .85 between the two CPS measures, and between the two ERDC measures.

Annual earned wages based on the first of these wage definitions vary over time, across discipline, and across different universities. Using a type-3 ANOVA, variation in log wages across disciplines explains $31 \%$ of all variation in wages across graduates, with year and campus attended respectively explaining $4 \%$ and $7 \%$ of wage variation. Fifty-eight percent of the $\log$ wage variation is unexplained by discipline, campus, or year.

When the mean wage is computed using the second wage definition (i.e., based on recent graduates of any of our eight public Washington universities), it becomes easy to see the stark differences between annual earned wages paid to graduates from different disciplines. Figure 4 illustrates full-sample mean wages for ten disciplines over the sample period. Earned wages differ strongly by field of study. In a given year, the standard deviation in wages between the disciplines each year is about $\$ 8,000$. Those with computing and information services degrees and health-related degrees earn the most, with first-year earnings of about $\$ 45,000$ per year. 
Most disciplines receive earnings below $\$ 25,000$ per year, and the least lucrative degrees, history, communications, and foreign language, lead to first-year earnings of $\$ 16,000-\$ 17,000$ per year.

[Insert Figure 4 here]

\section{Results}

\subsection{National Analysis}

Table 1 summarizes the results of our tests that prior wages in discipline $d$ Granger-cause bachelor's degrees in $d$ in year $t$. Wages are found to significantly Granger-cause majors for more than three-quarters of all majors when measured at either the 2- or 6-digit level. The weighted average p-value of the test of Granger-causality is 0.040 for the 362 -digit majors and 0.104 for the 1,0626 -digit majors. About $80 \%$ of all majors show a statistically significant correlation at the $95 \%$ level.

\section{[Insert Table 1 here]}

Table 2 shows the strength of the relationships between the awarding of bachelor's degrees in major $d$ in year $t$ and wages in major $d$ in year $t-y$. The estimated correlations are slightly larger at the 2-digit level than at the 6-digit level, with the peak correlations being 0.207 at $t-1$ for 2 -digit major groups and 0.140 at $t-3$ for 6 -digit majors. ${ }^{28}$ Squaring the peak 6-digit

\footnotetext{
${ }^{28} \mathrm{We}$ also explored the correlations of wages and majors at an even more aggregated level, with majors grouped into four categories: STEM (i.e., Science, Technology, Engineering, and Math); Humanities, Social Sciences, and Other). Our reason for exploring more aggregated categories is that the prior literature used more aggregated groups. Boudarbat et al. (2007) grouped majors into 7 groups (Education; Fine Arts and Humanities; Social Sciences; Commerce Business; Agriculture and Biological Sciences; Health; and Sciences), while Beffy et al. (2012) used 3 groups (Sciences; Humanities and Social Sciences; and Law, Economics, and Management). Averaging across our four major groups, the peak correlation of wages and majors was 0.154 at $t-1$. These results are not shown, but are available from the authors.
} 
correlation produces an R-squared of 0.02 . That is, variation in wages for all workers in affiliated occupations in year $t-3$ explains only about $2 \%$ of the variation in the production of bachelor degrees in year $t$. The weighted average effect of wages in 6-digit major $d$ in year $t-3$ on the share of bachelor's degrees going to major $d$ in year $t$ is $0.014 .{ }^{29}$ To put this figure into context, if major $d$ experienced a (large) 0.1 increase in relative wages, perhaps going from 1.0 (average wages) to 1.1 (10\% above average wages), then that major's share would be expected to rise by 0.0014 ( 0.14 percentage points). Note that the weighted average major has a share of all bachelor's degrees of $2.07 \%$. Thus, a 0.1 increase in relative wages would increase this average major's share from $2.07 \%$ to $2.21 \%$, for an elasticity of 0.67 .

Whether the response estimated above is large or small is in the eye of the beholder. We would characterize this level of responsiveness as "modest". We find a smaller percentage point effect, but a larger elasticity than Beffy et al. (2012) who, as we note above, estimate the relationship between earnings and majors using a fundamentally different approach applied to French students. They simulate that a $10 \%$ increase in wages would, respectively, lead to a 0.25 , 0.53 , and 0.40 percentage point increase in the share of students majoring in sciences; humanities and social sciences; and law, economics, and management. Yet, since they are evaluating relationships using aggregated major groups that have larger initial shares, the corresponding elasticities are far smaller $(0.09,0.14$, and 0.12 , respectively) than our estimated elasticity of 0.67. They characterize their results as "quantitatively small even though they are statistically significant" (p. 342), and we largely share this conclusion. ${ }^{30}$

\footnotetext{
29 These regression results are not shown, but are available from the authors.

${ }^{30}$ As shown in our working paper (Long et al., 2014), we find similar results for "all degrees" as we find for bachelor's degrees. We also explore whether the results are stronger when computing wages based on samples of CPS workers restricted to (1) only those aged 30 and under, (2) only those with a bachelor's degree, or (3) both restrictions. Our theory was that 4-year college students may be more responsive to the wages earned by individuals with a bachelor's degree
} 


\section{[Insert Table 2 here]}

Given the result in Table 1 that degree production responds significantly to wages in about $80 \%$ of majors, it is natural to ask what separates majors with strong responses from those that do not appear to be very responsive. Table 3 shows strong evidence supporting our hypothesis that students are more responsive to wages in majors that have tighter connections to particular occupations. The peak correlation between wages and majors is 0.345 for majors in the top-quartile, 0.238 for majors in the $2^{\text {nd }}$ quartile, and only $0.096(\mathrm{p}>0.10)$ for majors in the bottom-half of the distribution (i.e., those majors with the loosest connections to particular occupations). When evaluated as elasticities, the differences are striking. For majors whose connection to particular occupations is highest (i.e., in the top-quartile), the estimated elasticity of these majors with respect to their wages lagged three years is 2.35 ; a $10 \%$ increase in wages for these majors would raise their average major's share from $1.85 \%$ to $2.34 \%$. This estimated responsiveness is three-and-a-half times the size of the estimated elasticity for all majors (0.67), and we would characterize this response as "large". The peak elasticities fall monotonically as we move to majors progressively less connected to occupations: $1.89,0.65$, and 0.05 , respectively for the $2^{\text {nd }}, 3^{\text {rd }}$, and $4^{\text {th }}$ quartile.

\section{[Insert Table 3 here]}

Our second hypothesis is that students may have better information about wages for the largest, most popular majors, and thus may be more responsive to wage changes for those majors. In Table 4 we report model specifications that test this hypothesis. The first column of this table reproduces Table 1 column 1 for comparison. The subsequent columns of Table 4

and/or to those aged 30 and under as the wages of these persons may be a better signal of the college student's future labor market prospects. Yet, we find no evidence of stronger correlations. 
successively restrict the analysis to bigger and bigger majors. For example, as shown in column 2, $90 \%$ of bachelor's degrees are earned in 165 majors. However, the correlations are modestly smaller in column 2 than in column 1, thus these models fail to support the hypothesis that students respond more heavily to wage changes in larger majors. This result is maintained with further restrictions in column 3 (where 75\% of bachelor's degrees are earned in 64 majors) and column 4 (where $50 \%$ of bachelor's degrees are earned in only 17 majors). ${ }^{31}$

\section{[Insert Table 4 here]}

\subsection{Washington State Analysis}

Table 5 displays completed major response to wages in the Washington State sample. Each reported coefficient and average marginal effect is from a separate analysis. The responses in Table 5 are similar to those found at the national level in Section 5.1. We find that the largest significant marginal effect (0.024) is found for wages with a three-year lag based on recent graduates of public universities in the State of Washington. A marginal effect of 0.024 suggests that if a major saw its wages rise $10 \%$ more than other majors' wages in year $t-3$, then the share of students completing that major in year $t$ would increase by .24 percentage points. We would characterize this average response as modest, but also strikingly similar to the magnitude we find in the national analysis.

\section{[Insert Table 5 here]}

In general, the results in Table 5 suggest that there is more response to localized wage data. We see larger major responses when using either wages from prior students from their own university (column 1) or Washington State universities (column 2) than when using wages from a broader segment of workers in Washington (column 3) or national wages (column 4).

\footnotetext{
31 There is not a significant relationship between a major's size and the major's connection to particular occupations (i.e., its IQV score).
} 
It is unclear how a policymaker would characterize the responsiveness to the "localness" of labor market information shown in Table 5. On the one hand, greater responsiveness may help graduates get a well-paying job in the local labor market. On the other, if the local labor market trends are different from national trends, it could reduce the student's national labor market prospects and ultimately reduce the student's capacity for mobility and ability to respond to general economic need for particular workers. Such reduced mobility may lead to higher unemployment as it limits the ability of labor markets to adequately adjust to shifts in labor demand (Bound and Holzer, 2000; Holzer, 1991).

Table 6 shows how the marginal response to changes in wages differs for various student subgroups. For this analysis, we look at responsiveness to wages of graduates of the student's own university in year $t-3$. The first average marginal effect shown on Table 6 is 0.015 across all students. ${ }^{32}$ Below this, we show how this marginal effect varies across demographic characteristics. We find that males respond substantially more to changes in major-specific wages than females ( 0.023 versus 0.009$)$, which is consistent with the findings of Boudarbat and Montmarquette (2007) that in general men respond more strongly than women to initial earnings. We also find that black and Hispanic students respond less than white and Asian students (-0.006 and -0.003 versus 0.016 and 0.019$).{ }^{33} \mathrm{~A}$ low, and possibly negative, response to wages for black students is consistent with findings on the response of college enrollment to changes in the wage return (Kane 1994, Beattie 2002). Students with high SAT scores respond much more strongly to wages than students with low SAT scores (0.020 versus 0.004$)$ and slightly more strongly than

\footnotetext{
${ }^{32}$ For comparison, the average marginal effect is 0.011 across all students when campus fixed effects are included in the specification as shown in the $t$ - 3 row of column 1 in Table 5.

${ }^{33}$ Males and whites are slightly more likely to choose majors with tight mappings to particular occupations; IQV scores by group are as follows: Men (.928) vs. Women (.932); Whites (.931) vs. Blacks (.937).
} 
those who do not report SAT scores (0.020 versus 0.017$)$. By contrast, there is little evidence of differences in the responsiveness based on students' FRPL status.

\section{[Insert Table 6 here]}

Table 6 shows that student responsiveness to wage changes differs significantly across groups. Interestingly, individuals from groups with higher labor market earnings (whites, Asians, men, and high-SAT scorers) tended to be more responsive than those with lower earnings; the exception is FRPL status where we did not observe a difference in responsiveness. We are not able to distinguish whether these differences across groups are due to differences in preferences, or differences in the constraints on major choice faced by members of these groups.

\section{Conclusions}

In this paper we find that students' completed majors respond positively to longitudinal changes in relative wages. We characterize the average response as modest, but generally consistent with other work investigating the connection between labor market earnings and college major choices (e.g. Beffy et al., 2012). This result is not terribly surprising. To the degree that students and/or colleges would like to respond to changes in the labor market, there is a severe lack of information available which would allow lead to well-informed responses. Information about earnings associated with particular majors is sparse, and generally relegated to academic studies. Information about earnings based on occupations is more readily available, and increasingly so, but students and colleges attempting to use this information face another stumbling block: occupations are often linked to many majors and vice-versa. Consequently, they have to make assumptions about the mapping of majors into occupations and track the wages associated with a wide range of outcomes. 
However, looking at major response to wages in detail, we find heterogeneity in the response. Given the difficulty in tracking wages and observing the labor market, perhaps it is not surprising that students/colleges are more responsive to wage changes in majors that are closely associated with particular occupations. While the response for the average major has an elasticity of 0.67 , a tightly-connected major has an elasticity of 2.35 .

Our findings from Washington State suggest that students/colleges are more likely to respond to localized information about earnings than national information, which may well be desirable since there are good arguments for better alignment between education systems and labor demand (Holzer, 2012). But it does not necessarily follow that policymakers ought to push for the provision of more localized information about the returns to particular majors. As we have shown, the provision of this sort of information requires some guesswork about how majors map onto occupations, and, more generally, the provision of information may or may not predict the true long-run economic prospects of majoring in a particular field. Moreover, given that sectoral shifts do not always align at the local and national levels (Bound and Holzer, 2000), it is possible that a response to local labor market information could serve to limit students' national labor market mobility.

Regardless of the efficacy of trying to shape individuals' college major choices, it appears that this is the direction in which policy is heading. Some differential tuition policies aim to put more students into high-demand majors, and President Obama has proposed a plan to publicly rate colleges in part based on the earnings of graduates..$^{34}$ Inherent in these plans is the idea that degree production responds to the demands of the labor market, whether this responsiveness occurs at the level of the student or in changes in college offerings.

\footnotetext{
34 This plan has met with some resistance (Shear, 2014) and has, consequently, not yet been implemented.
} 
Interventions which aim to improve student responsiveness to labor market cues with information provision alone run into a problem in that responsiveness to the labor market is modest to begin with. These interventions would also need to take into account the timing of information; we find that completed majors in year $t$ respond most strongly to wages observed in year $t-3$ when those graduates were approximately freshmen. We also find that majors respond more strongly in disciplines where information is more salient and applicable.

By making information more salient and applicable, it is possible that major response could rise further. These sorts of informational or motivational campaigns may be particularly important for certain student groups. Women, black and Hispanic students, and those with low SAT scores do not respond as strongly as other students. We cannot say whether this differential response might be related to heterogeneous preferences, the wage information that is received by these subgroups of students, or their ability to respond to wage information while in college. However, these issues merit further investigation. It is possible that increasing the student/college response to wages, especially the response of these groups, and shifting these students into high-demand majors may alleviate some of the wage gaps that exist in the workforce. 


\section{References}

ACT. 2014. Compare SAT \& ACT Scores. http://www.act.org/solutions/college-careerreadiness/compare-act-sat/

Alstadsæter, Annette. 2011. Measuring the consumption value of higher education. CESifo Economic Studies 53: 458.

Altonji, Joseph G., Blom, Erica, \& Meghir, Costas. 2012. Heterogeneity in human capital investments: high school curriculum, college major, and careers. NBER Working Paper 17985.

American Association of Colleges of Nursing. 2009. Student enrollment expands at U.S. nursing colleges and universities for the 9th year despite financial challenges and capacity restraints. http://www.aacn.nche.edu/news/articles/2009/09enrolldata.

Arcidiacono, Peter. 2004. Ability sorting and the returns to college major. Journal of Econometrics 121 (1-2): 343-375.

Arcidiacono, Peter, V. Joseph Hotz, and Songman Kang. 2012. Modeling college major choices using elicited measures of expectations and counterfactuals. Journal of Econometrics 166 (1) (January): 3-16.

Beattie, Irenee R. 2002. Are all 'adolescent econometricians' created equal? racial, class, and gender differences in college enrollment. Sociology of Education 75 (1): 19-43.

Beffy, Magali, Denis Fougère, and Arnaud Maurel. 2012. Choosing the field of study in postsecondary education: do expected earnings matter? Review of Economics and Statistics 94 (1): 334-347.

Berger, Mark C. 1988. Predicted future earnings and choice of college major. Industrial and Labor Relations Review 41: 418-429. 
Betts, Julian R. 1996. What do students know about wages? Evidence from a survey of undergraduates. Journal of Human Resources, 31 (1): 27-56.

Boskin, Michael J. 1974. A conditional logit model of occupational choice. The Journal of Political Economy 82 (2): 389-398.

Botelho, Anabela, \& Pinto, Ligia C. 2004. Students' expectations of the economic returns to college education: results of a controlled experiment. Economics of Education Review, 23 (6): 645-653.

Boudarbat, Brahim, and Claude Montmarquette. 2007. Choice of fields of study of Canadian university graduates: the role of gender and their parents' education. IZA Discussion Paper No. 2552.

Bound, John, and Harry J. Holzer. 2000. Demand shifts, population adjustments, and labor market outcomes during the 1980s. Journal of Labor Economics 18 (1): 20-54.

Buchinsky, Moshe, and Phillip Leslie. 2010. Educational attainment and the changing U.S. wage structure: dynamic implications on young individuals' choices. Journal of Labor Economics, 28(3): 541-594.

Cameron, Colin A., Jonah B. Gelbach, and Douglas L. Miller. 2008. Bootstrap-based improvements for inference with clustered errors. The Review of Economics and Statistics. 90 (3): 414-427.

Carnevale, Anthony P., Ban Cheah, and Jeff Strohl. 2012. Hard times, college majors, unemployment and earnings: not all college degrees are created equal. Georgetown University Center on Education and the Workforce. http://www9.georgetown.edu/grad/gppi/hpi/cew/pdfs/Unemployment.Final.update1.pdf, Accessed September 26, 2013. 
Carnevale, Anthony P., Jeff Strohl, and Michelle Melton. 2011. What's it worth? The economic value of college majors. Georgetown University Center on Education and the Workforce. http://cew.georgetown.edu/whatsitworth/, Accessed September 26, 2013.

Cataldi, Emily F., Caitlin Green, Robin Henke, Terry Lew, Jennie Woo, Brian Shepherd, Peter Siegel, and Ted Socha. 2011. 2008-09 Baccalaureate and beyond longitudinal study (BB:08/09): first look (NCES 2011-236). U.S. Department of Education. Washington, DC: National Center for Education Statistics.

Ehrenberg, Ronald G. 2012. American higher education in transition. The Journal of Economic Perspectives 26 (1): 193-216.

Freeman, James A., \& Hirsch, Barry T. (2008). College majors and the knowledge content of jobs. Economics of Education Review, 27 (5): 517-535.

Gibbs, Jack P., and Dudley L. Poston. 1975. The division of labor: conceptualization and related measures. Social Forces 53 (3): 468-476.

Goldin, Claudia, \& Katz, Lawrence C. (2008). The Race Between Education and Technology. Harvard University Press.

Goodreau, Jenna. 2012. The 10 worst college majors. Forbes. http://www.forbes.com/sites/jennagoudreau/2012/10/11/the-10-worst-college-majors/, Accessed August 5, 2013.

Granger, Clive WJ. 1969. Investigating causal relations by econometric models and crossspectral methods. Econometrica 37 (3): 424-438.

Holzer, Harry J. 1989. Employment, unemployment and demand shifts in local labor markets. The Review of Economics and Statistics 73 (1): 25-32. 
Holzer, Harry J. 2012. Good workers for good jobs: improving education and workforce systems in the US. IZA Journal of Labor Policy 1 (5): 1-19.

Izzo, Phil. 2012. Which college majors pay best. Wall Street Journal, April 17.

Kane, Thomas J. 1994. College education of blacks since 1970: the role of college costs, family background, and the returns to education. Journal of Political Economy 102 (5): 878911.

Liu, Kai, Kjell Salvanes, and Erik Sorensen. 2012. Good skills in bad times: cyclical skill mismatch and the long-term effects of graduating in a recession. NHH Dept. of Economics Discussion Paper 16 .

Long, Mark C., Dan Goldhaber, and Nick Huntington-Klein. 2014. Do students' college major choices respond to changes in wages?, CALDER Working Paper 107.

Meyer, Peter B., and Anastasiya M. Osborne. 2005. Proposed category system for 1960-2000 census occupations. U.S. Bureau of Labor Statistics, Working Paper 383, September.

National Bureau of Economic Research. 2013. CPS merged outgoing rotation groups. http://www.nber.org/data/morg.html.

National Public Radio. 2013. What's your major? Planet Money, Episode 485, September 11, http://www.npr.org/blogs/money/2013/09/11/221417806/episode-485-whats-your-major

National Center for Education Statistics. 2007. The path through graduate school: a longitudinal examination 10 years after bachelor's degree. Washington, D.C.

—. 2013. The Condition of Education 2013. Washington, D.C.

— 2013. Classification of Instructional programs (CIP 2000). http://nces.ed.gov/pubs2002/cip2000/, Accessed August 5, 2013.

NCES/BLS. 2011. Guidelines for using the CIP-SOC crosswalk. National Center for Education 
Statistics and Bureau of Labor Statistics, http://nces.ed.gov/ipeds/cipcode/resources.aspx?y=55, Accessed August 5, 2013.

Olson, Elizabeth G. 2012. Underemployed grads: suffering from college major remorse? Fortune, July 18.

Oreopoulos, Philip, Till von Wachter, and Andrew Heisz. 2012. The short- and long-term career effects of graduating in a recession. American Economic Journal: Applied Economics 4 (1): $1-29$.

Payscale, Inc. 2013. Majors that pay you back, http://www.payscale.com/college-salary-report2013/majors-that-pay-you-back, Accessed August 5, 2013.

Ransom, Michael R. 2014. The changing occupational distribution by college major. Working paper, Brigham Young University, June.

Reich, Michael, David M. Gordon, and Richard C. Edwards. 1973. A theory of labor market segmentation. American Economic Review 63 (2): 359-365.

Shear, Michael D. 2014. Colleges Rattled As Obama Seeks Rating System. New York Times, May 25.

Singletary, Michelle. 2012. Not all college majors are created equal. Washington Post, January 14.

Siow, Aloysius. 1984. Occupational choice under uncertainty. Econometrica 52 (3): 631-645.

Stange, Kevin M. 2015. The effect of differential pricing on undergraduate degree production by field. Journal of Policy Analysis and Management 34(1): 107-135.

Stekler, H. O., and Rupin Thomas. 2005. Evaluating BLS labor force, employment, and occupation projections for 2000. Monthly Labor Review, July, 46-56. 
Stewart, James B. 2013. New metric for colleges: Graduates' salaries. The New York Times, September 14.

Stinebrickner, Ralph, and Todd R. Stinebrickner. 2014. A major in science? Initial beliefs and final outcomes for college major and dropout. The Review of Economic Studies 81 (1): 426-472.

U.S. Census Bureau. 2013. 2010 occupation code list. http://www.census.gov/people/eeotabulation/data/2010_OccCodeswithCrosswalkfrom20 02-2011nov04.xls, Accessed August 6, 2013.

Wiswall, Matthew, and Basit Zafar. 2015. Determinants of college major choice: identification using an information experiment. Review of Economic Studies, 82 (2) 791-824.

Zafar, Basit. 2011. How do college students form expectations? Journal of Labor Economics, 29 (2): $301-348$.

Zarkin, Gary. 1985. Occupational choice - an application to the market for public-school teachers. The Quarterly Journal of Economics 100 (2): 409-446. 
Figure 1: Demand for and Supply of Labor in Occupations Associated with Major $d$, and the Weighted Average Equilibrium Wage and Labor in These Occupations

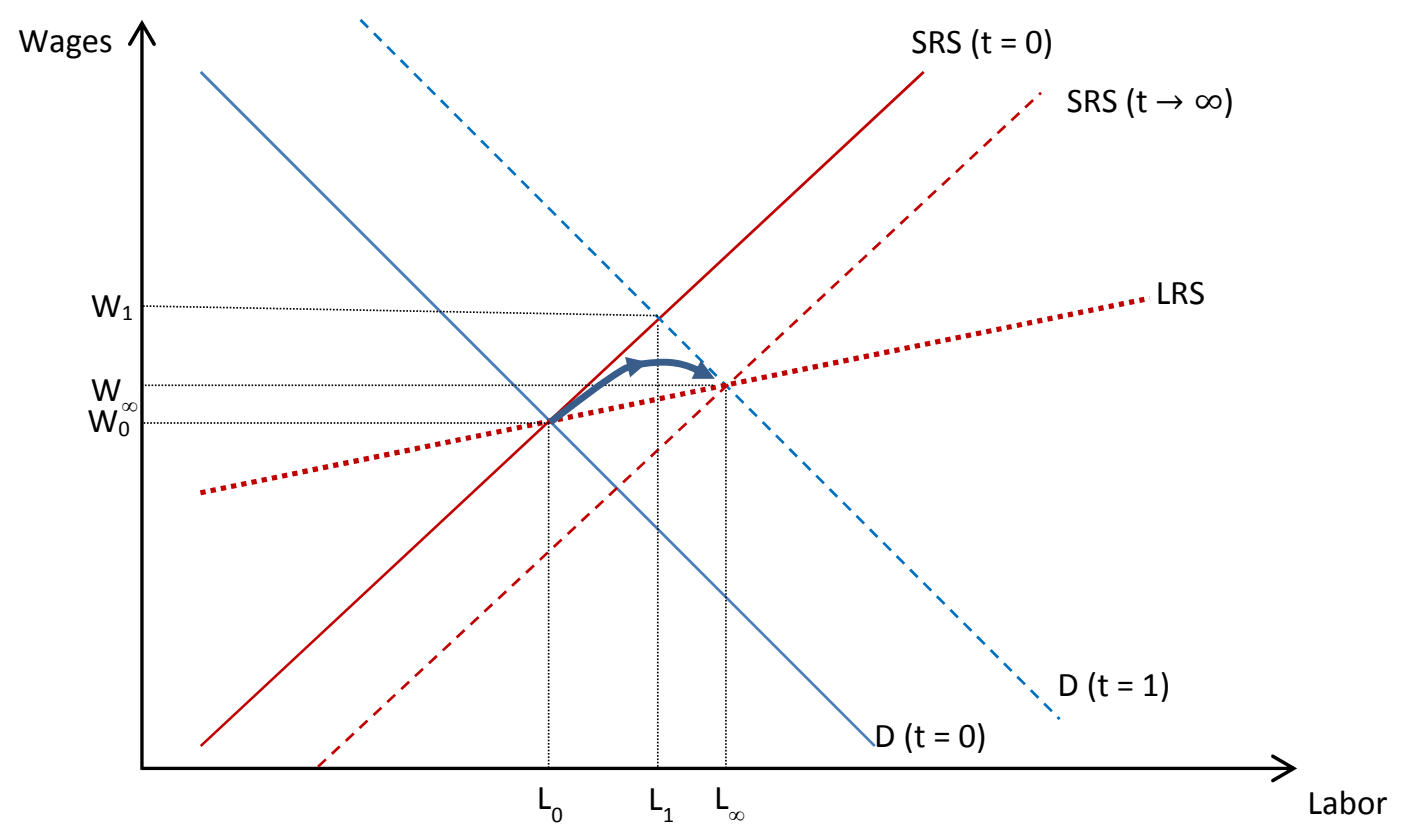




\section{Figure 2: Wage Impulse Response Functions for the 30 Most Popular Majors}

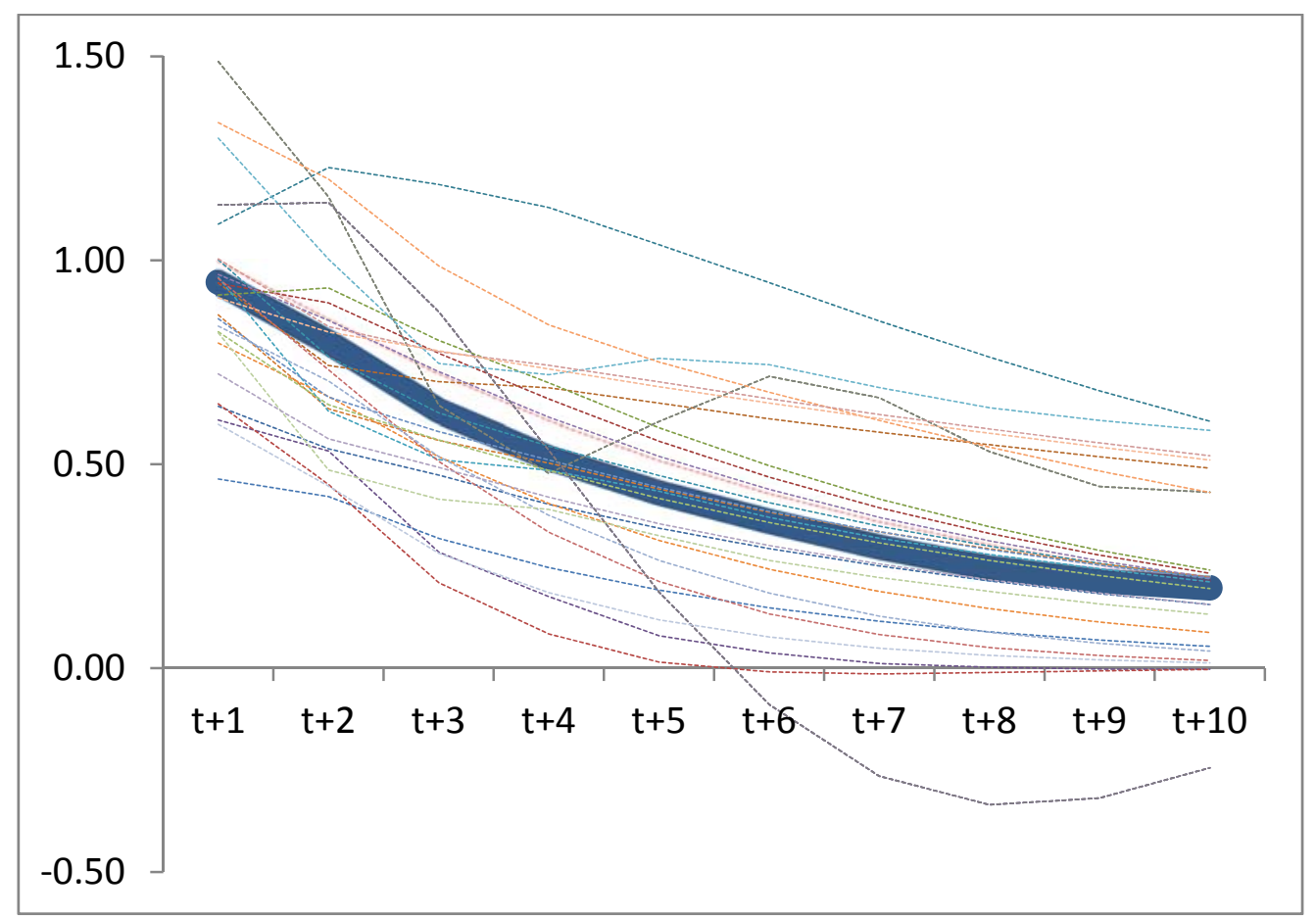

Authors' calculations based on weighted averages of wage data by occupation from the 1983 to 2012 Current Population Survey's Merged Outgoing Rotation Groups, with weights based on occupational employment by major as found for ACS survey respondents in the years 2009 to 2011. The thick line reflects the mean of the 30 individual impulse response functions. 
Figure 3: Wages and Share of Bachelor's Degrees in "Nursing” (i.e. Registered Nurse Training)

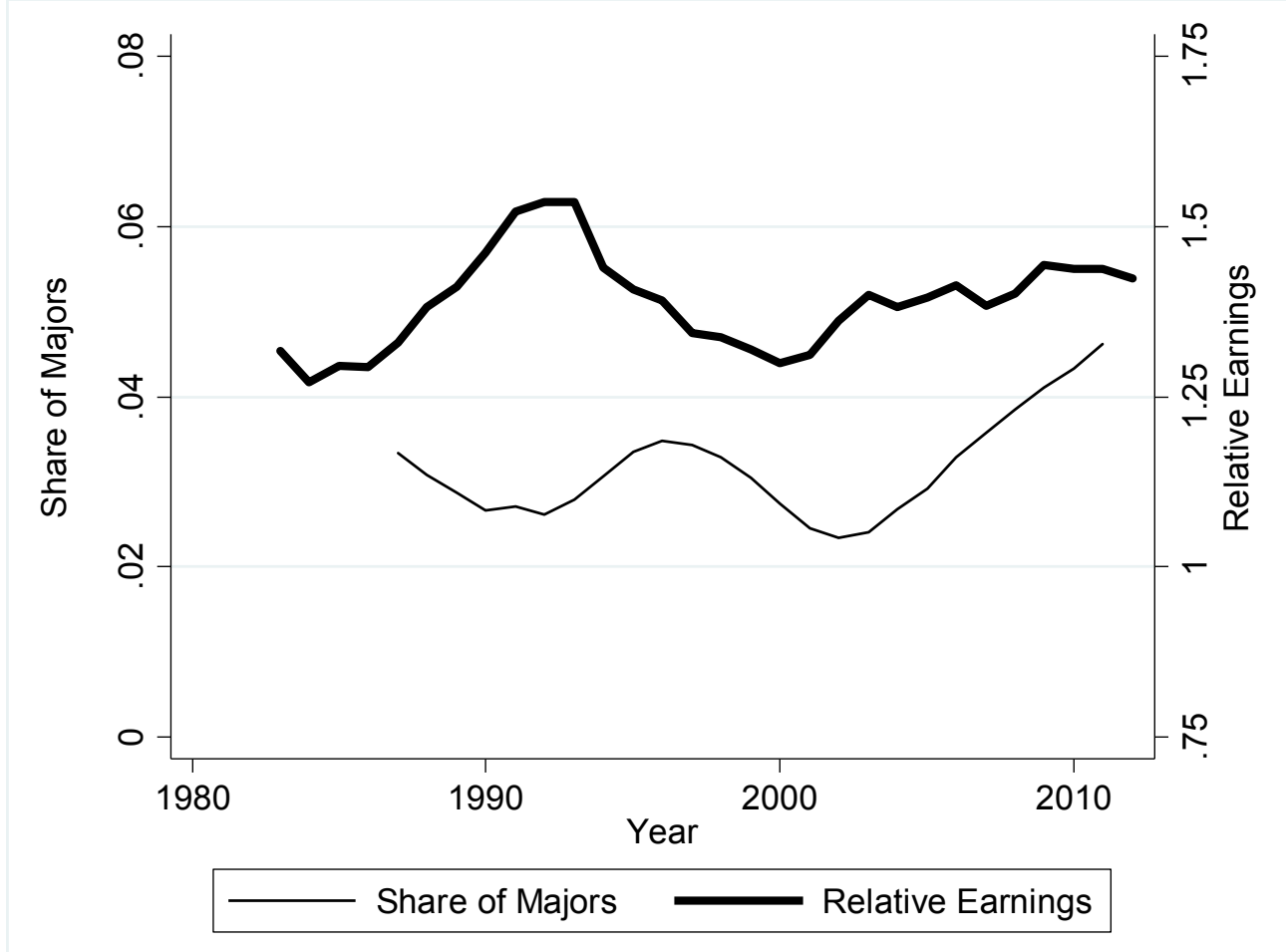

Completed majors for the years 1987 to 2011 are taken from the Integrated Postsecondary Education Data System (IPEDS), collected by the U.S. Department of Education. Relative wages are calculated based on weighted average of wage data by occupation from the 1983 to 2012 Current Population Survey's Merged Outgoing Rotation Groups, with weights based on occupational employment by major as found for ACS survey respondents in the years 2009 to 2011. 
Figure 4: Mean First-Year Wages in Ten Selected Disciplines over Time

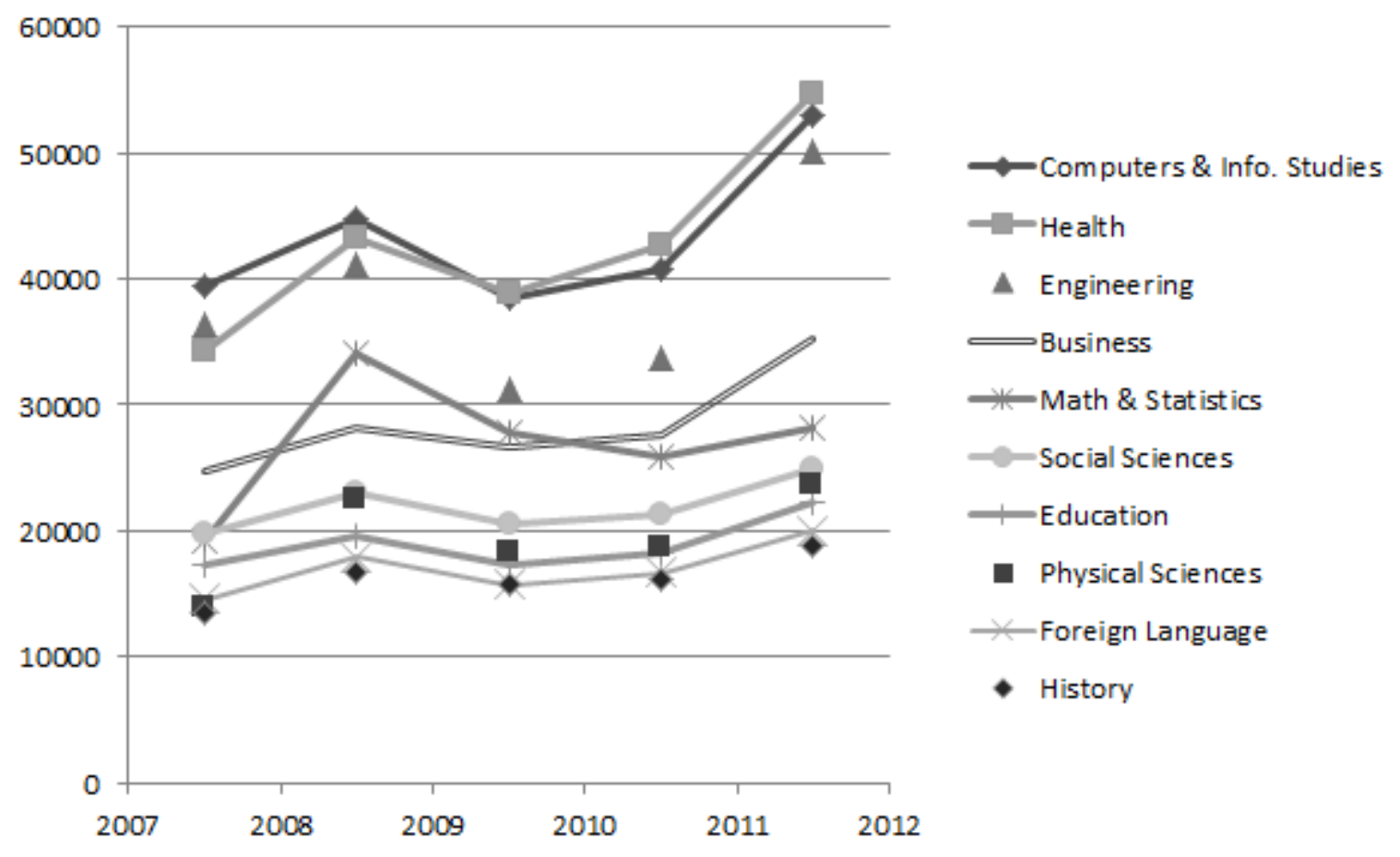

Based on data from Unemployment Insurance records for 58,511 students who graduated with a bachelor's degree from one of eight large public universities in Washington between fall 2007 and spring 2011. 
Table 1: Does Wages in Years $t-1$ to $t-6$ Granger Cause Majors in Year $t$ ?

\begin{tabular}{lcc} 
& \multicolumn{2}{c}{ CIP Code Level: } \\
& 2-Digit & 6-Digit \\
\hline Weighted Average P-Value & $0.040 * *$ & $0.104 \quad+$ \\
Total Majors Evaluated & 36 & 1,062 \\
Majors with P-Value $<=0.1$ & 32 & 899 \\
& $(89 \%)$ & $(85 \%)$ \\
Majors with P-Value $<=0.05$ & 29 & 840 \\
& $(81 \%)$ & $(79 \%)$ \\
Majors with P-Value $<=0.01$ & & \\
& 28 & 721 \\
& $(78 \%)$ & $(68 \%)$ \\
\hline
\end{tabular}

Note: $* * *, * * *$, and + denote weighted average $\mathrm{p}$-value at or below the $1 \%, 5 \%, 10 \%$, and $15 \%$ levels respectively. Granger test conducted using six lags of wages and six lags of majors used to predict majors in year $t$. Completed majors for the years 1987 to 2011 are taken from the Integrated Postsecondary Education Data System (IPEDS), collected by the U.S. Department of Education. Wages for each major are calculated based on weighted average of wage data by occupation from the 1983 to 2010 Current Population Survey's Merged Outgoing Rotation Groups, with weights based on occupational employment by major as found for ACS survey respondents in the years 2009 to 2011. 
Table 2: Correlation Between Majors Produced in Year $t$ and Associated Occupational Wages in Year $t-y$

\begin{tabular}{lcccc} 
& \multicolumn{4}{c}{ CIP Code Level: } \\
Wages Measured in Year: & 2-Digit & \multicolumn{2}{c}{ 6-Digit } \\
\hline$t-1$ & $\mathbf{0 . 2 0 7}$ & $* *$ & 0.111 & $* *$ \\
& $\mathbf{( 0 . 0 9 2 )}$ & & $(0.048)$ & \\
$t-2$ & 0.206 & $* *$ & 0.130 & $* * *$ \\
& $(0.097)$ & & $(0.049)$ & \\
$t-3$ & 0.199 & $*$ & $\mathbf{0 . 1 4 0}$ & $* * *$ \\
& $(0.103)$ & & $(\mathbf{0 . 0 5 1 )}$ & \\
$t-4$ & 0.175 & $*$ & 0.135 & $* * *$ \\
& $(0.101)$ & & $(0.051)$ & \\
$t-5$ & 0.150 & + & 0.132 & $* * *$ \\
& $(0.095)$ & & $(0.051)$ & \\
& 0.110 & & 0.116 & $* *$ \\
& $0.087)$ & & $(0.050)$ & \\
\hline
\end{tabular}

Note: Standard errors of the correlations are in parentheses.

$* * *, * *, *$, and + denote two-tailed significance at the $1 \%, 5 \%$, $10 \%$, and $15 \%$ levels respectively. Bolded values reflect the peak correlation for the column. Completed majors for the years 1987 to 2011 are taken from the Integrated Postsecondary Education Data System (IPEDS), collected by the U.S. Department of Education. Wages for each major are calculated based on weighted average of wage data by occupation from the 1983 to 2010 Current Population Survey's Merged Outgoing Rotation Groups, with weights based on occupational employment by major as found for ACS survey respondents in the years 2009 to 2011. 
Table 3: Is the Observed Correlation Between Majors and Wages Higher for Majors with "Tighter" Connections to Particular Occupations?

(1)

\begin{tabular}{|c|c|c|c|c|c|c|}
\hline $\begin{array}{l}\text { Connection of Major to } \\
\text { Occupations }\end{array}$ & $\begin{array}{c}\text { Tightest: } \\
\text { Top- } \\
\text { Quartile }\end{array}$ & & $\begin{array}{c}\text { Tightest: } \\
\text { 2nd- } \\
\text { Quartile }\end{array}$ & & $\begin{array}{c}\text { Loosest: } \\
\text { Bottom- } \\
\text { Half }\end{array}$ & \\
\hline Wages Measured in Year: & \multicolumn{6}{|c|}{ Correlation (S.E.) } \\
\hline \multirow[t]{2}{*}{$t-1$} & 0.222 & $* *$ & 0.142 & + & 0.064 & \\
\hline & $(0.092)$ & & $(0.092)$ & & $(0.057)$ & \\
\hline \multirow[t]{2}{*}{$t-2$} & 0.276 & $* * *$ & 0.175 & $*$ & 0.081 & \\
\hline & $(0.104)$ & & $(0.092)$ & & $(0.060)$ & \\
\hline \multirow[t]{2}{*}{$t-3$} & 0.308 & $* * *$ & 0.214 & $* *$ & 0.096 & + \\
\hline & $(0.115)$ & & $(0.090)$ & & $(0.059)$ & \\
\hline \multirow[t]{2}{*}{$t-4$} & 0.336 & $* * *$ & 0.232 & $* * *$ & 0.088 & + \\
\hline & $(0.123)$ & & $(0.086)$ & & $(0.058)$ & \\
\hline \multirow[t]{2}{*}{$t-5$} & 0.345 & $* * *$ & 0.238 & $* * *$ & 0.089 & + \\
\hline & $(0.125)$ & & $(0.082)$ & & $(0.057)$ & \\
\hline \multirow[t]{2}{*}{$t-6$} & 0.328 & $* * *$ & 0.228 & $* * *$ & 0.083 & + \\
\hline & $(0.121)$ & & $(0.081)$ & & $(0.052)$ & \\
\hline
\end{tabular}

Note: $* * *, * *, *$, and + denote two-tailed significance at the $1 \%, 5 \%, 10 \%$, and $15 \%$ levels respectively. Bolded values reflect the peak correlation for the column. Completed majors for the years 1987 to 2011 are taken from the Integrated Postsecondary Education Data System (IPEDS), collected by the U.S. Department of Education. Wages for each major are calculated based on weighted average of wage data by occupation from the 1983 to 2010 Current Population Survey's Merged Outgoing Rotation Groups, with weights based on occupational employment by major as found for ACS survey respondents in the years 2009 to 2011. 
Table 4: Is the Observed Correlation Between Majors and Wages Higher for the Larger Majors?

\begin{tabular}{lcccc} 
& $(1)$ & $(2)$ & $(3)$ & $(4)$ \\
\hline $\begin{array}{l}\text { Share of all Bachelor's } \\
\text { Degrees }\end{array}$ & $100 \%$ & $90 \%$ & $75 \%$ & $50 \%$ \\
$\begin{array}{l}\text { Number of Distinct Majors } \\
\text { Included }\end{array}$ & 1,101 & 165 & 64 & 17
\end{tabular}

Wages Measured in Year:

Correlation (S.E.)

\begin{tabular}{cccccccccc}
\hline$t-1$ & 0.111 & $* *$ & 0.103 & $* *$ & 0.106 & $*$ & 0.106 & $*$ \\
& $(0.048)$ & & $(0.049)$ & & $(0.063)$ & & $(0.063)$ & \\
$t-2$ & 0.130 & $* * *$ & 0.118 & $* *$ & 0.121 & $*$ & 0.121 & $*$ \\
& $(0.049)$ & & $(0.050)$ & & $(0.064)$ & & $(0.064)$ & \\
$t-3$ & $\mathbf{0 . 1 4 0}$ & $* * *$ & $\mathbf{0 . 1 2 4}$ & $* *$ & $\mathbf{0 . 1 2 7}$ & $*$ & $\mathbf{0 . 1 2 7}$ & $*$ \\
& $\mathbf{( 0 . 0 5 1 )}$ & & $\mathbf{( 0 . 0 5 2 )}$ & & $\mathbf{( 0 . 0 6 6 )}$ & & $\mathbf{( 0 . 0 6 6 )}$ & \\
$t-4$ & 0.135 & $* * *$ & 0.115 & $* *$ & 0.116 & $*$ & 0.116 & $*$ \\
& $(0.051)$ & & $(0.051)$ & & $(0.066)$ & & $(0.066)$ & \\
$t-5$ & 0.132 & $* * *$ & 0.108 & $* *$ & 0.106 & $*$ & 0.106 & $*$ \\
& $(0.051)$ & & $(0.050)$ & & $(0.064)$ & & $(0.064)$ & \\
$t-6$ & 0.116 & $* *$ & 0.084 & $*$ & 0.079 & & 0.079 & \\
& $(0.050)$ & & $(0.049)$ & & $(0.062)$ & & $(0.062)$ & \\
\hline
\end{tabular}

Note: $* * * * *, *$, and + denote two-tailed significance at the $1 \%, 5 \%, 10 \%$, and $15 \%$ levels respectively. Bolded values reflect the peak correlation for the column. Completed majors for the years 1987 to 2011 are taken from the Integrated Postsecondary Education Data System (IPEDS), collected by the U.S. Department of Education. Wages for each major are calculated based on weighted average of wage data by occupation from the 1983 to 2010 Current Population Survey's Merged Outgoing Rotation Groups, with weights based on occupational employment by major as found for ACS survey respondents in the years 2009 to 2011. 
Table 5: Does Students' Choices of Majors Respond More to Wages Received by Recent Graduates in their State?

\begin{tabular}{|c|c|c|c|c|c|c|c|}
\hline & (1) & & $(2)$ & & (3) & & (4) \\
\hline Source of Wage Data & UI & & UI & & CPS & & CPS \\
\hline Level of Wage Data & $\begin{array}{c}\text { Recent } \\
\text { Graduates of } \\
\text { Own University }\end{array}$ & & $\begin{array}{c}\text { Recent } \\
\text { Graduates of } \\
\text { Eight Public } \\
\text { Universities in } \\
\text { Washington } \\
\text { State }\end{array}$ & & $\begin{array}{c}\text { Washington } \\
\text { State Bachelor's } \\
\text { Degree Holders }\end{array}$ & & $\begin{array}{c}\text { National } \\
\text { Bachelor's } \\
\text { Degree Holders }\end{array}$ \\
\hline Wages Measured in Year: & \multicolumn{7}{|c|}{ Coefficient (S.E.) [Average Marginal Effect] } \\
\hline \multirow[t]{3}{*}{$t-1$} & 0.062 & $*$ & 0.137 & $*$ & 0.317 & $* * *$ & -0.295 \\
\hline & $(0.035)$ & & $(0.073)$ & & $(0.087)$ & & $(0.381)$ \\
\hline & {$[0.002]$} & & {$[0.006]$} & & {$[0.013]$} & & {$[-0.012]$} \\
\hline \multirow[t]{3}{*}{$t-2$} & -0.047 & & -0.177 & $* *$ & 0.039 & & 0.333 \\
\hline & $(0.045)$ & & $(0.083)$ & & $(0.068)$ & & $(0.338)$ \\
\hline & {$[-0.001]$} & & {$[-0.007]$} & & [0.002] & & [0.013] \\
\hline \multirow[t]{3}{*}{$t-3$} & 0.267 & $* * *$ & 0.572 & $* * *$ & 0.116 & $*$ & 0.203 \\
\hline & $(0.083)$ & & $(0.172)$ & & $(0.062)$ & & $(0.317)$ \\
\hline & {$[0.011]$} & & {$[0.024]$} & & {$[0.005]$} & & {$[0.008]$} \\
\hline
\end{tabular}

Note: $* * *, * *, *$, and + denote two-tailed significance at the $1 \%, 5 \%, 10 \%$, and $15 \%$ levels respectively. Standard error of $\beta$ is in parentheses. Average marginal effect is in brackets. Each estimated coefficient comes from a separate alternative-specific conditional logit, which varies the level, source, and lag for wage data. Major data for 58,511 students who graduated with a bachelor's degree from one of eight large public universities in Washington between fall 2007 and spring 2012. 
Table 6: Heterogeneity in the Response of Students' Completed Majors in Year $t$ to Local Labor Market Wages in Year $t-3$

\begin{tabular}{|c|c|c|c|c|c|}
\hline \multirow{2}{*}{$\begin{array}{l}\text { Student Group } \\
\text { All Students }\end{array}$} & \multicolumn{2}{|c|}{$\begin{array}{l}\text { Marginal } \\
\text { Response }\end{array}$} & \multirow[t]{2}{*}{ Student Group } & \multicolumn{2}{|c|}{$\begin{array}{l}\text { Marginal } \\
\text { Response }\end{array}$} \\
\hline & 0.015 & $* * *$ & & & \\
\hline & $(0.002)$ & & & & \\
\hline \multirow[t]{2}{*}{ Males } & 0.023 & $* * *$ & Non-FRPL Recipient & 0.018 & $* * *$ \\
\hline & $(0.003)$ & & & $(0.004)$ & \\
\hline \multirow[t]{3}{*}{ Females } & 0.009 & $* * *$ & FRPL Recipient & 0.018 & $* * *$ \\
\hline & $(0.003)$ & & & $(0.007)$ & \\
\hline & & & Missing FRPL Status & 0.018 & $* * *$ \\
\hline Difference $(F-M)$ & -0.015 & $* * *$ & (Out of State Students) & $(0.004)$ & \\
\hline \multirow[t]{2}{*}{ Non-Hispanic Whites } & 0.016 & $* * *$ & Difference (FRPL - Non) & 0.001 & \\
\hline & $(0.002)$ & & Difference (Miss - Non) & $<0.001$ & \\
\hline \multirow[t]{2}{*}{ Non-Hispanic Blacks } & -0.006 & & & & \\
\hline & $(0.022)$ & & SAT Score Above 1000 & 0.020 & $* * *$ \\
\hline \multirow[t]{2}{*}{ Non-Hispanic Asians } & 0.019 & $* * *$ & & $(0.004)$ & \\
\hline & $(0.009)$ & & SAT Score Below 1000 & 0.004 & \\
\hline \multirow[t]{3}{*}{ Hispanics } & -0.003 & & & $(0.005)$ & \\
\hline & $(0.010)$ & & Missing SAT Score & 0.017 & $* * *$ \\
\hline & & & & $(0.004)$ & \\
\hline Difference $(B-W)$ & -0.023 & + & & & \\
\hline Difference $(A-W)$ & 0.002 & & Difference (Low - High) & -0.016 & $* *$ \\
\hline Difference $(H-W)$ & -0.020 & $* *$ & Difference (Miss - High) & -0.003 & $* *$ \\
\hline
\end{tabular}

Note: $* * *, * *, *$, and + denote two-tailed significance at the $1 \%, 5 \%, 10 \%$, and $15 \%$ levels respectively. Standard error of the marginal effect is in parentheses. Wage data is taken from UI records for recent graduates of the student's own university. Major data for 58,511 students who graduated with a bachelor's degree from one of eight large public universities in Washington between fall 2007 and spring 2012. 